\title{
A public pastoral assessment of the interplay between 'she was created inferior' and cultural perceptions of women by Christian men in Zimbabwe as accessory to gender-based violence
}

\begin{tabular}{|c|c|}
\hline \multicolumn{2}{|c|}{$\begin{array}{l}\text { Authors: } \\
\text { Vhumani Magezi }^{1} \\
\text { Peter Manzanga }^{1}\end{array}$} \\
\hline \multicolumn{2}{|c|}{$\begin{array}{l}\text { Affiliations: } \\
{ }^{1} \text { Department of Christian } \\
\text { Ministry and Leadership, } \\
\text { Faculty of Theology, } \\
\text { North-West University, } \\
\text { Potchefstroom, South Africa }\end{array}$} \\
\hline \multicolumn{2}{|c|}{$\begin{array}{l}\text { Corresponding author: } \\
\text { Vhumani Magezi, } \\
\text { vhumani@hotmail.com }\end{array}$} \\
\hline \multicolumn{2}{|c|}{$\begin{array}{l}\text { Dates: } \\
\text { Received: } 19 \text { Aug. } 2020 \\
\text { Accepted: } 16 \text { Feb. } 2021 \\
\text { Published: } 25 \text { Mar. } 2021\end{array}$} \\
\hline \multicolumn{2}{|c|}{$\begin{array}{l}\text { How to cite this article: } \\
\text { Magezi, V. \& Manzanga, P., } \\
2021 \text {, 'A public pastoral } \\
\text { assessment of the interplay } \\
\text { between 'she was created } \\
\text { inferior' and cultural } \\
\text { perceptions of women by } \\
\text { Christian men in Zimbabwe } \\
\text { as accessory to gender-based } \\
\text { violence', Verbum et Ecclesia } \\
42(1), \text { a2139. https://doi. } \\
\text { org/10.4102/ve.v42i1.2139 }\end{array}$} \\
\hline \multicolumn{2}{|c|}{$\begin{array}{l}\text { Copyright: } \\
\text { (C) 2021. The Authors. } \\
\text { Licensee: AOSIS. This } \\
\text { is licensed under the } \\
\text { Creative Commons } \\
\text { Attribution License. }\end{array}$} \\
\hline \multicolumn{2}{|l|}{ Read online: } \\
\hline 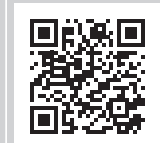 & $\begin{array}{l}\text { Scan this QR } \\
\text { code with your } \\
\text { smart phone or } \\
\text { mobile device } \\
\text { to read online. }\end{array}$ \\
\hline
\end{tabular}

The notion woman were created 'inferior' and its interplay with the negative cultural perceptions of women by Christian men arguably act as an accessory to gender-based violence (GBV) in the church. Hence, there is a need for the church to rethinks and continually discerns the implications of the creation of man and woman in Genesis 1:26-27 and 2:18. The following question arise: Does the creation of man and woman in Genesis assume women inferiority? What is the interplay between the notion 'she was created inferior' and negative cultural perceptions of women? How could the church interrogate this interplay to improve gender relations within church and local cultural contexts? This article utilises a public pastoral care approach as a theoretical lens that the church could employ to address women inferiority as a form of GBV. Firstly, the article examines the interplay between 'she was created inferior' and negative cultural gender relations in church that fan GBV. Secondly, it assesses Genesis 1:26-27; 2:18 and 3:1-6 in the context of man and woman creation to discern God's ideal plan for gender relations. Thirdly, the article establishes how a positive conception of Genesis 1 and 2 could transform certain cultural understandings of women that fan GBV in church. Fourthly, the article proposes public pastoral care roles for the church to mitigate the perception of women inferiority as GBV in church and community.

Intradisciplinary and/or interdisciplinary implications: The article considers sociocultural factors that cause GBV and evaluates the phenomenon from a theological perspective to develop GBV ecclesiological interventions. Thus, it considers GBV from a socio-theological and biblical framework. Accordingly, it uses an interdisciplinary approach.

Keywords: gender-based violence; women inferiority to men; women creation; public pastoral care; cultural perceptions of women; church and GBV.

\section{Introduction}

Attention has been given to abusive gender relations in ecclesial institutions (Chitando \& Chirongoma 2013:9; Clark 2016:iv; Ushe 2015:99). Chisale (2020:1) cites Mwaura (2005) who states that female membership in African churches is $80 \%$ but women continue to experience and persevere gender inequality. Women become part of a particular denomination because of its practices based on theological tenants. However:

$[W]$ hat they might get and did not bargain for is second place status ... second best, somehow less blessed and worthy in the eyes of ecclesia and by transference in the eyes of God also. (Chisale 2020; Meyer 2020; Ndulo 2011; Rayburn 2015:26; Rakoczy 2004)

The situation of women under some church leaders remains deplorable. Damron \& Johnson (2015) articulates:

... [W]omen have been placed in a one-down, inferior position by patriarchal systems, they have often been quite reticent to speak up for themselves and indeed may not even be sensitive to their victim role in abusive situations with power-seeking and dominance-craving male persons. (p. 29)

The notion of women's inferiority by Christian men in church emanates from the belief that women were 'created inferior to men'. This view springs from and is sustained in churches through invalid interpretation of certain biblical passages. For example, one of the interpretations is that Eve was created from the man's rib and was named by Adam. Hence, some argue that women owe their very existence to men as subordinates (Rayburn 2015:31). 
Clark (2016:36) states that 'Violence among families of faith reflects the cultures they inhabit, but interweaving the narrative is their faith and religious identity'. Practically, there is an interplay between cultural mores and religious behaviour. Transference of patriarchal patterns is evident in Christian teachings and these promote gender-based violence (GBV) in Zimbabwe and even control the status of women in Church and communities (Kambarami 2006:5). According to Lerner (1986:239), patriarchy is the manifestation and institutionalization of male dominance over women and children in the family and the extension of male dominance over women in society in general'. A passage like Genesis 2:18 is taken as the bedrock that aids extension of patriarchy from culture to religion. The creation of Eve as 'second' and as a 'helper' for Adam remains bent towards patriarchy. The submission of women and headship of men in Ephesians 5:22-24 are also negatively understood in a way that drags patriarchy into religion (Stephens \& Walker 2015:209). The unequal social relations that exist in the family set up as an institution are replicated in the church reinforced through invalid interpretation of scripture. Hence, women remain subordinate in ways that do not allow them to contradict and expose men. This makes most women prone to GBV in the church.

\section{According to Vuola (2016):}

$[M]$ ost of the patriarchal claims about women's nature, roles, rights and position, not only inside a given religious community but in society at large, are based on authoritative religious texts and their interpretation ... (p. 326)

This entails that the treatment of women as inferior to men in religious institutions forms a foundational springboard of GBV in churches. The underlying perception entrenched in most Christian men is that women were created subservient to men and cannot make independent decisions other than men (Brade 2009:24). The notion of women's inferiority to men has been sustained historically as proven in the following two examples. Firstly, Rayburn (2015:30) refers to Ross (1912) who expressed that 'Aristotle proffered that women exist as natural deformities or imperfect males (perhaps referring to the lack of the male sexual appendage?)'. As such, women have been denigrated in a manner that made them feel insignificant and always subservient to men. Secondly, Rayburn (2015) further cites Freeland (1994) who advances that Aristotle expressed that:

$[W]$ omen were inferior to men, saw men as commanding and women as obeying; females as incomplete males were deformities who passed on only matter to their offspring whereas men passed on form. (p. 30)

Such negative perceptions continue to be natured in the church and existing culture although expressed differently.

An invalid understanding of the creation of man and woman in Genesis 1:26-27 and 2:18 serves as a background from which women's inferiority to men comes from. The invalid interpretation has an interplay with the already male dominant culture of Christian men in Zimbabwe. The notion of women's inferiority to men forms the primary foundational differences on gender relations in Zimbabwe. This is demonstrated through strict controls placed on women whilst their male counterparts enjoy freedom in and outside marriage (Njovana \& Watts 1996:49). It is expected of Christian men in Zimbabwe to violate cultural norms and values without being held accountable or questioned by women. On the contrary, women who show disregard for cultural norms and values may risk being beaten or divorced depending on the severity of their disobedience (Amnesty International 2004:iii-iv).

This entails that invalid interpretation of Genesis 1:26-27 and Genesis 2:18 on God's ideal plan for gender relations finds a 'fertile ground' (Chisale 2020:1) in ecclesial environment in Zimbabwe. As 'inferior' counterparts in homes, church and broader community of faith, women cannot exercise authority over men. In a church setting, it might be considered better to have a drunken man lead a programme than allowing a woman to lead. This is done simply to assert male authority and dominance because 'women were created by God inferior'. Citing Chifungo (2015), Chisale (2020:2-3) advances that Christian men in ecclesial settings hide 'behind the Bible and culture' to sustain female inferiority in the church as GBV. Whilst God creates people in a culture and ordains culture for His glory, there are certain practices in culture to keep, to change and to reconsider (Grand 2013:vi). Ozaki and Otis (2017) argue that:

$[I] \mathrm{t}$ is important to underscore that it is not individual cultures that are problematic in terms of support or even promotion of violence against women, but rather aspects of patriarchy embedded within culture that serve to maintain and sustain these norms. (p. 1077)

This means patriarchy is nurtured in culture by most Christian men in Zimbabwe. Patriarchy amongst Christian men is further '... nurtured by androcentric biblical interpretations that are gender biased' (Chisale 2020:2). A Christian man's understanding of the creation of woman affects what it would also mean to be religious as a man. This implies an interplay between being male and being religious. In her article, Investigating the nature of and relation between masculinity and religiosity and/or spirituality in a postcolonial and post-apartheid South Africa, Meyer (2020) rightfully states that:

... [R]eligiosity/spirituality ... relates with and informs men's notion of masculinity, their cultural values and the degree to which they are involved in both marriage and parental responsibilities ... these constructs interact with each other in a distinct manner to produce a specific ... masculinity, which in turn informs the social construction of a 'Christian man': who should be a Christian man, and how should such a man behave. (p. 2)

Though Meyer is writing with a South African context in mind, the argument raised accurately mirrors the Zimbabwean context as well. The interplay she raises informs and defines what it means to be male in religion and determines the manner in which males should behave 
(Meyer 2020:2). Not only does religion/spirituality define masculinity but it also presupposes how women should behave in relation to men (Meyer 2020:2). Relationally, certain religious beliefs are understood as encouraging male dominance and submission of women (Brown 2015:2). In Zimbabwe, most Christian men come from male-dominated homes in which women remain inferior. If religion defines masculinity in a manner that encourages women domination, it means certain traditional (cultural) practices find a fertile ground at church (Brown 2015; Chisale 2020; Hoffmann \& Miller 1997; Meyer 2020:2; Moore \& Vanneman 2003). In the end, there is an interrelationship on what it means to be male at home and church and the same applies to women too. Meyer (2020:5) further advances that notions of gender roles and responsibilities would have developed from traditions communicated from and within a faith-based institution (based on specific theologies), and integrated into a specific culture and extended to gender operations within the familial home and, at times, the workplace. Gender relations in the Zimbabwean church-setting remain crucial as a determining issue about how men relate to women. Given that Genesis 1:26-27 and 2:18 seems to be the background from which women's 'inferiority' originates, the question that emerges is: what is God's ideal plan for gender relations between men and women that promotes human flourishing in both church and broader society? The following section seeks to assess Genesis 1:26-27 and 2:18 as foundational biblical passages utilised to sustain women's inferiority in ecclesia and the broader community.

\section{Discerning God's ideal plan for gender relations between man and woman from Genesis 1:26-27 and 2:18}

The following question is pertinent to guide the discussion: Does scripture assume hierarchical differences between men and women as the basis of gender relations? (Sproul 2011:143). If there are differences, how could we understand them in a manner that promotes constructive gender relations? An analysis of Genesis 1:26-27 and 2:18 is foundational to discern gender relations between Adam and Eve (Foh 1974:376; Maisiri 2015). It is important to examine God's ideal design on gender relations between men and women. The discussion below is divided into three sections regarding gender relations between men and women.

\section{Man and woman created in the image of God}

Genesis 1:26-27 states that Adam and Eve were created in the image $^{1}$ of God. Genesis 1:26 states:

Then God said, Let us make man in our image, after our likeness. And let them have dominion over all the fish of the sea and over the birds of the heaven and over the livestock and over all the earth and over every creeping thing that creeps on the earth.

1.For more rigorous and detailed engagement on the views about the image of God I refer the reader to Magezi and Magezi (2018). I also refer the reader to Simango (2016).
So, God created man in his own image, in the image of God he created him; male and female he created them. (ESV 2015:13)

It is important at this point to establish the meaning of what it means to be created in the image of God. The understanding that emerges from this brief section is going to serve as the primary basis for viewing men and women in relation to GBV in this article. There are divergent views in biblical interpretation regarding the image of God in human beings.

Firstly, scholars have postulated a physical view of the image of God in human beings. Zimmerli (1978:35) and Atkinson (1990:36) argue that some scholars view the physical appearance of man as representing the image of God. Some have argued that the incarnation of Christ could be attributed to God manifesting himself in physical form. This view is not convincing because scripture teaches that God is Spirit (Jn 4:24) (Magezi \& Magezi 2018:4). Man cannot resemble God in his total uniqueness as Psalm 8:1-9 states and God is incorporeal (De La Torre 2011; Kidner 1967; Magezi \& Magezi 2018; Simango 2006, 2016; Zimmerli 1978:36). Concisely, 'This means that although people are created in the image of God, it follows that there is a robust distinction between humankind and God' (Magezi \& Magezi 2018:4). Grudem (1994) further states that:

... [T] o picture God as existing in a form or mode of being that is like anything else in creation is to think of God in a horribly misleading and dishonouring way. (p. 284)

This view fails to give a convincing understanding of the image of God.

Secondly, the image of God in human beings is understood as moral, rational and spiritual emanating from Genesis 1:26-27 (Magezi \& Magezi 2018:4; Simango 2006:4). Citing Atkinson (1990), Magezi and Magezi (2018:5) posit that the moral, rational and spiritual aspects reflect something in man about the image of God. This could mean that human beings, created by God, have the moral ability to relate to God and to one another in faith, love, compassionate care and obedience (Magezi \& Magezi 2018; cf. Atkinson 1990; De La Torre 2011; Eveson 2001; Hamilton 1990). This viewpoint suggests a better understanding of the image of God in humans in that humans have the same conscious moral, rational and spiritual capacity as their maker. This helps humanity to live for God and for others on earth (De La Torre 2011:24).

Thirdly, the relational view of the image of God states that human beings have the ability to have a relationship with God and man-to-man (Barth 1960 cited in Atkinson 1990; Simango 2006:16; Westermann 1987). The idea of man being able to relate to God in the absence of sin and also to his fellow men seems to express better the image of God in Genesis 1:26-27 (Magezi \& Magezi 2018:6). Magezi and Magezi (2018) further refer to Atkinson who advances that this view allows for '... relationship in which God places himself with human beings, a relationship in which we become God's counterpart, his representative and his glory 
on the earth' (Atkinson 1990:37). This is suggestive of what true humanity should be like on earth in the context of human situations that seek to marginalise and oppress other human beings.

The fourth and last view of the image of God in humanity is the functional view. This view holds that man exists on earth to represent the incorporeal God by ruling over the earth (Magezi \& Magezi 2018:6, cf. Arnold 2009; Clines 1968; Hart 1995; Moltmann 1991; Simango 2006). Magezi and Magezi (2018:6) advance that proponents of this view may have been influenced by Genesis 1:28 which refers to being fruitful, multiplying and subduing the earth. Both Adam and Eve were able to be fruitful, multiply and rule over the earth as equal bearers of the image of God. According to Magezi and Magezi (2018:6), to view the functional view as being able to procreate and fill the earth has its own weakness, which some scholars overlook. The reason advanced is that the human race can no longer exercise dominion over the earth and others as God intended because of the fall in Genesis 3 (Magezi \& Magezi 2018:6; Wenham 1987). Through the fall, humanity transitioned from its high state to a degeneration that seeks to oppose and grossly misrepresent its creator. Consequently, citing De La Torre (2011), Magezi and Magezi (2018) further state that:

There is a tendency for those who are in positions of influence in various spheres of human society to forget that they are part and parcel of God's creation. This is because the human understanding of having dominion and rule over the word is corrupted by sin to the extent that those who are in power have a tendency of misunderstanding 'to rule' as to place themselves 'over and above' creation, and consequently overlook that they are to rule for the well-being of the creation that includes other humans. (p. 6)

Whilst it remains valid that God mandated man (Adam and Eve) to have dominion over the earth as a reflection of God's image, how should dominion be exercised by sinful humanity? This now calls for godly justice, love and compassion and servanthood in reflecting the dominion as part of the image of God in humanity (Magezi \& Magezi 2018:6, cf. Atkinson 1990:41; Simango 2006).

From the above discussion, it emerged that the image of God in human beings is understood as moral (rational and spiritual), relational and functional. Although the body serves to physically express how we relate to God and to one another, the physical view of the image of God lacks sound and convincing biblical basis because God is incorporeal. Thus, in the context of GBV, the three views underpin the understanding of the image of God in men and women. Now, given that men and women equally possess the image of God, this should transform the way men and women view and relate to each other as creatures of God.

\section{Man and woman created equal}

From the above discussion, if man and woman were equally created in the image of God, it follows that men and women are equal in God's eyes. What does male and female equality mean? Ortlund defines it as, 'Man and woman are equal in the sense that they bear God's image equally' (Ortlund 1991:95). When God caused the woman to come to Adam, Adam expressed his excitement and amazement at the sight of Eve. We read Adam's exuberant expression upon beholding Eve in Genesis 2:23, 'This at last bone of my bones and flesh of my flesh; she shall be called Woman, because she was taken out of man'. In Adam's eyes, Eve is part of him as expressed in the words, 'bone one my bones and flesh of my flesh' (Hamilton 1990:179). Eve is equal to him and nothing else in all creation, as he saw in the name of animals (Gn 2:19-20) (Wenham 1987:70).

Hamilton, citing Brueggemann (1982), states that the formula in Adam's expression 'is a covenant formula and that it speaks not of a common birth but of a common, reciprocal loyalty' (Hamilton 1990:179). If it is a reciprocal loyalty, it suggests that neither of the two should dominate and abuse the other, but both should live in a harmonious and mutual relationship in a manner that equally reflects the image of God. This kind of relationship as laid out in Genesis is the ideal foundation even for contemporary marriage relationships. Hamilton (1990) further advances that:

The verse does not attribute strength to the man and weakness to the woman, as if he is the embodiment of bone and she is the embodiment of flesh. Both the man and the woman share the entire spectrum of human characteristics, from strong to weak. (p. 180)

This clearly puts man and woman in Genesis 2:19-20 on an equal footing that is free from superiority, domination, abuse and inferiority. Waltke and Fredricks (2001:89) state that 'In ancient times the authority to name implied authority to govern'. Does having authority and governance over the other imply inferiority of the other? Sproul (2011:144) states that 'Because a person is given a subordinate position in a given structure that involves a division of labour does not carry with it the necessary inference of inferiority'. The implication is Adam would lead Eve in a manner that displays reciprocal love, equality and respect for Eve as opposed to oppressive and sinful male authority. Genesis 2:23 naturally suggests verse 24 and in Genesis 1:28, they were already blessed by God to procreate and both were given the right to have dominion over creation. The following section discusses that neither of them (Adam and Eve) was self-sufficient, but each lived in support of and need of the other as equal bearers of the image of God.

\section{Man and woman complement each other}

Man and woman complement each other. In Genesis 2:18, God said, 'It is not good that the man should be alone; I will make him a helper fit for him'. Implicit in this verse is the impression that there are distinctions between a man and a woman when God created them (Gillham 2011:3). If both have differences, this equally suggests that each is not selfsufficient but would need the help of the other. Our attention 
is drawn to companionship that is direly needed between man and woman. The woman is called a 'helper', and this does not mean that she is stronger than Adam, but simply the one being assisted is inadequate by himself. The word 'helper' does not imply that Eve had to become Adam's servant, rather she had to exist and work alongside Adam as an equal human being (Assohoto \& Ngewa 2006:14). The idea of complementarity is further suggested here rather than identity ${ }^{2}$ (Wenham 1987:68). If complementarity is in force, this means both had biological, strength, ability and relational needs that prompted them to be suitable, fit or corresponding for each other in a mutual relationship.

From the preceding discussion, both man and woman were created in the image of God and they should reflect the likeness of God in their relationship to one another. Neither of them bears more image of God than the other. Both are equal in the eyes of their Creator for Adam rejoiced at seeing someone similar and equal to him. The fact that the woman is called a helper does not suggest that she is inferior, but she simply complements a lack in the other person. As they practised their roles, God expected unity, mutuality, understanding and ultimately love without domineering or abuse of each other. Both were equally blessed by God without lowering the value of the other. It is an atmosphere where Eve was not inferior to Adam or less human. In doing so, they reflected the kind of life that God had designed for them as people of different sexes. God set the standard of gender relations between men and women for the rest of humanity to follow. Adam and Eve's environment had no inferiority as a notion of GBV. So where did the notion of GBV originate from?

\section{The disruption of the image of God in Adam and Eve}

Genesis 3 comes after the broad context of creation (Gn 1 and 2) where Adam and Eve were able to perfectly show the image of God. Thus, until Chapter 3, Adam and Eve were able to relate to God and as a couple in absolute moral purity and function as God's representatives in the universe for God's glory. Genesis 3 begins by introducing the reader to the serpent and his character (Gn 3:1). This analysis assumes that the serpent or the tempter is the devil as alluded in Revelation 12:93 and 20:2. The following scholars are also of the opinion that the devil spoke through the snake as a vehicle to convey his message (Simango 2006:41, cf. Briggs 1886:71-72; Greidanus 2004:267; Hengstenberg 1956:14-17; Vawter 1956:64, 67). The character of the serpent reveals moral deficiency and a complete contradiction of what could be referred to as the image of God. As such, the tempter was crafty or cunning in a bad sense. An allusion to such a

2.'If identity were meant, the more natural phrase would be "like him". The help looked for is not just assistance in his daily work or in the procreation of children, though these aspects may be included, but the mutual support companionship provides' (Wenham 1987:68).

3.Revelation 12:9, And the great dragon was thrown down, that ancient serpent, who is called the devil and Satan, the deceiver of the whole world-he was thrown down to the earth, and his angels were thrown down with him (ESV). Revelation 20:2 alludes to almost the same reading as in 12:9. character is found in Ezekiel 20:11-18, which is about prince of Tyre but, in retrospect, echoes to the tempter's character.

The tempter utilised his flawed character to mislead Adam and Eve from relating to God perfectly and between them as a couple. Genesis 2:25 reveals that 'And the man and his wife were both naked and were not ashamed'. Regarding their nakedness, Ross (1985) comments:

Their nakedness represented the fact that they were oblivious to evil, not knowing where the traps lay, whereas Satan did and would use his craftiness to take advantage of their integrity. (p. 32)

Thus, focusing on their innocence, the tempter plants doubt in the mind of Eve, 'Did God actually say, You shall not eat of any tree in the garden?' (Gn 3:1). In Genesis 3:3-5 (English Standard Bible [ESV]), the tempter added that:

... [Y] ou will surely not die ... For God knows that when you eat of it your eyes will be opened, and you will be like God, knowing good and evil. (p. 8)

After successfully instilling doubt, the tempter accuses God in front of Eve that He (God) is hiding something from her, which is, He does not like her to be like him. The tempter labelled God a liar (Currid 2003:119; Greidanus 2004:268; Ross 1985:32). The serpent is suggesting that humanity could be better than God (Simango 2006:4). The woman was left to her natural desires (Assohoto \& Ngewa 2006:15; Ross 1985:32) and succumbed to the temptation, thereby disobeying the commandment of God in Genesis 2:17, '... but of the tree of the knowledge of good and evil you shall not eat, for in the day that you eat of it you shall surely die'. The woman shared the fruit with her husband (verse 6) and after this, '... the eyes of both were opened, and they knew they were naked ...' (Gn 3:7). There is also a change in roles in Genesis 3 when Eve took the lead to speak with the serpent and lead the husband to eat of the tree (3:2-6). The woman usurps the role of a spokesperson on behalf of the husband (Hamilton 1990:188) and this is contrary to the complementing plan of God and projecting the image of God.

Their innocence or lacking active knowledge and awareness to sin had been taken away. They felt exposed and vulnerable. Ross states that they became ill at ease with one another and ill at ease with God (Boice 1982:143; Ross 1985:32). Assohoto and Ngewa (2006:16) advance that 'In their relationship with each other, openness had been replaced by shame, mistrust, instability and superficiality'. Simango (2006:42, cf. Kline 1993:78) advises that they opted to equate themselves with God who rightfully advises what is good and not good.

The Genesis 3 narrative evokes a wide range of interpretations in ecclesia that tag the woman as weak, more vulnerable to sex, sinner, gullible and so on (cf. 2 Cor 11:3; 1 Tim 2:11-15). The interpretations are possible but lack contextual and textual support (Hamilton 1990:188). Genesis 3:6 reads that Adam was with Eve, '... she took of its fruit and ate, and she also gave 
some to her husband who was with her, and he ate' (Gen 3:6). This entails that Adam was equally sinful and equally responsible for the fall (Wilkinson 2002:69) and equally had the image of God in him marred. As for now, what is clear is that after the fall, things were never the same relationally amongst God, man and woman. God pronounced a curse on the serpent and judgement on the woman and man (Gn 3:14-19). It is interesting to note that God said to the woman in Genesis 3:16, 'Your desire shall be for your husband, and he shall rule over you'. There are other interpretations on this verse, but the one forwarded by Collins (2006) addresses this section better and is relevant to this article. He states:

We conclude that God describes a condition of human marriages that is all too familiar, namely, competition for control. Sin has corrupted both the willing submission of the wife and the loving headship of the husband. The woman's desire is to control her husband and he must master her if he can. (p. 176)

The reality amongst Christian men and women is that the verse casts a shadow on gender relations because of the marred image of God. On the contrary, Genesis 3:15 is suggestive of hope of restoration, 'I will put enmity between you and the woman, and between your offspring and her offspring; he shall bruise your head, and you shall bruise his heel'. The verse anticipates the coming of the Saviour who will model true humanity amongst other things and restoration of gender relations. Magezi and Magezi (2018:6) substantiate that 'it is through Christ, the very God himself that humanity can be restored back to their perfect relationship with God and with one another'. A model for true humanity is pertinent because the image of God has been distorted in humanity.

Therefore, Adam and Eve wilfully disobeyed and abandoned their relationship with God. The relational, moral and functional aspects of the image of God in them were marred. They were unable to relate to God (vertically) and to each other (horizontally) in a manner that brings honour to God. They decided what was good in their own eyes and rejected the relational and moral likeness, which they had enjoyed in fellowship with God (Simango 2006:43) and between themselves. Boice (1982) states:

When the connection with God is broken, irresponsibility, cowardice, lying, jealousy, hatred and every other evil descended on the race ... the wish to blame others, plus self-interest and the desire to self-advancement, produce the conflict between individuals, races, social stratifications, institutions and nations which so mar human history. (p. 143)

Thus, men and women in communities possess a marred image of God such that treating each other in a manner that reflects God's image has almost become impossible. Living for God and for each other in gender relations comes with complications and this is suggestive of GBV. To that end, the role of the church should not remain private. Thus, a public pastoral care role by the church is pertinent to redress the misconception of women inferiority in both the church and the broader community.

\section{Public theology and public pastoral care in the context of women inferiority}

Public pastoral care is utilised to understand and frame suggestions on how Christian men in Zimbabwe could change within churches and broader society. In public pastoral care, the community of faith has a role to act on its behalf and broader community towards transformation (Graham 2000:1; Masango 2010). This means public pastoral care is both a 'public discourse and contextual enterprise' (Bezuidenhout \& Naude 2002:3). The church should be able to identify its contextual cultural perceptions or understandings about women that encourage an interplay with the notion that women are created inferior and acknowledge such interplay as GBV. This entails that together with the community, the church could challenge the status quo when it does not promote human flourishing (McClure 2012:189)

This assists in bringing public pastoral care to the fore for the benefit of the church and the community. The congregation and the communal context serve as the focus of pastoral care (McLemore 2018:316) as opposed to a situation whereby pastoral care is confined to congregants alone. McLemore (2018:316 cites Graham (1992) who further advises that pastoral care should address issues of 'individualism, subjectivity and privacy'. This means even in interpretation of biblical passages, churches cannot continue to favour interpretations that fan GBV. Instead, interpretations that affirm and uphold women as fully created in the image of God should lead to transformation within the community of faith and broad ministerial context. Public pastoral care should focus on allowing the biblical text to analyse, inform and frame solutions to women experiences of inferiority in both culture and church.

Working towards transformation for change in cultural perceptions of women by men does not come about easily. Ministers of the gospel should be able to analyse cultural practices, '... enter and organize communities for action, and balance ministry to individuals in crisis with social advocacy' (McLemore 2018:317). In this situation, 'the link between public theology and pastoral is easily discernible' (Magezi 2019:3). The suffering that women endure in church, at home and community regarding inferiority of women is sustained by invalid interpretation of scripture and cultural conception of women. This means, used as a broader theoretical lens on public issues of society, public theology informs how the church should practice public pastoral care on women 'inferiority' in church and culture. Bromell (2011) states the following about public theology as a border theoretical lens:

It reflects critically on the ethical and political implications, here and now, of claims expressed or implied in religious faith and witness, and does so in the public sphere, in publicly accessible ways. (p. 4) 
This entails that public theology acts as a medium through which public pastoral care interacts with an issue like the notion of women's inferiority and its interplay with culture. Citing Levesque (2014), Magezi (2019:4) argues that that public theology has been practised by the vanguard of individuals calling for a reimagining of how Christians engage with the world around them'. This means that the church should encounter with public issues affecting members and broader community such as GBV. Practically, the church forms a context in which the gospel:

... [C] an be mediated and realised. As an embodiment of koinoniathe fellowship of believers, the congregation forms the context in which pastoral encounter can take place. Encounter means the communication process that takes place between God and humanity within a real situation where they discover meaning through faith and guided by scripture ... pastoral encounter is humane and contextual. (Louw 1998:70; Potgieter 2015:3)

Christian men should be able to understand what it means to be humane to women in a manner that reflects God's ideal plan for gender relations. This means treating women as created in the image of God. Public pastoral care should encounter with the real conception that women are inferior. Such notion should be reimagined by the church, guided by valid interpretation of scripture and practically lived out in the public space.

Christianity has the potential to address GBV (Koening 1998 in Meyer 2020:6). The question at hand is: how could the church formulate an understanding that does not perpetuate abusive cultural and church practices about women inferiority? The following public pastoral care proposals serve as guides towards curbing women's inferiority in both the church and traditional culture of Christian men.

\section{Public pastoral care proposals to mitigate against women inferiority in church and community}

Firstly, the church through its pastors should intentionally revisit and seek to understand biblical passages that seem to be misunderstood as treating women as inferior to men. Primary to such an understanding is the need to understand that men and women are equally created in the image of God. Men do not have more of the image of God over women. Valid interpretations should evoke positive responses in a church and cultural context where women are treated inferior to men. The responses should be relevant to the context of both the church and broader community (Darragh 2007:4). This helps to put into better perspective God's ideal gender relations for men and women in spite of the fact that the image of God in men and women was marred. It is still possible for men and women to live in a manner that reflects ideal gender relations in a fallen state. Amongst other passages, Ephesians 5:21-33 should be brought to the fore in trying to curb GBV played out in women's inferiority by men in the church and culture. The passage expects men and women to live in harmony and upholding the dignity of the other as each fulfils the God given responsibilities.
Secondly, if the premise for practising public pastoral care is love for God and one's neighbour, it follows that for the church and its leadership, the biblical text remains the demarcating factor in ministerial context. God has revealed himself through the biblical text in specific life transforming ways both spiritually and physically. Likewise, the pastor has a task to study the text and draw principles that address the ministerial context to evoke transformation on women inferiority as a form of GBV. This means purposeful contextual bible studies that seek to address women inferiority as GBV should be part of the churches' annual planning (Chindomu \& Matizamhuka 2013:172).

Thirdly, the church cannot continue to focus on itself alone in doing pastoral care. Rather, the impact of the church becomes meaningful when it reaches out to the community by addressing public issues that affect people. Changing cultural perceptions and practices presents itself with resistance and rejection. The structural social context of the community has an effect on violence and sharing of power (Louw 1998:75). This entails that the church should collaborate with community leaders and community members to engage in dialogue who revisit cultural perceptions that continue to treat women as inferior to men. Together, they should frame better ways of amending such perceptions in a manner that uphold the dignity of women and curb GBV. This helps to transform not only the church but also broader community and reinstates what it means to be a church in a ministerial context on public issues.

Fourthly, as many GBV issues have to do with invalid biblical interpretation, the church should develop skills for ministerial contextual analysis and applying the biblical text in public pastoral care. The task of public pastoral care by the church must be considered within its context and the implications of our theological reflections would be more relevant (Bosch 1995:35). Many churches in Zimbabwe necessitate that every pastor should develop skills to interact and engage in ministerial contextual analysis. This will assist in applying the biblical passages with relevance to GBV issues found in a particular context. Understanding of the contextual location of the congregation(s) and community(s) in which one serves is understood as, 'the heart of pastoral care rather than the expert pastor' (McLemore 2018:316). Garner (2015:21), in his article, Contextual and public theology: Passing fads or theological imperatives, states that 'contextual theology enables us to make sense of God and ourselves in and through the world in which we find ourselves embedded, in a particular time and place'. This is important because human experience is couched in the context where theological dialogue and refection take place (Garner 2015:21).

\section{Conclusion}

The invalid interpretation of Genesis 1:26-27, 2:18 and the subsequent marring of the image of God in man and woman in Genesis 3 disrupted the ideal gender relations for men 
and women. The passages have been used as a basis for treating women as inferior to men in both the church and traditional cultural settings.

As the church encounters its invalid interpretation, it should also collaborate with community leaders and broader community to reassess cultural perceptions that continue to treat women as inferior to men. This means that the church should engage in public pastoral care to interact with the notion of women's inferiority to men and frame positive responses. Such responses should uphold the dignity of men and women as equally created in the image of God in church ministerial context and broader community.

\section{Acknowledgements Competing interests}

The authors declare that they have no financial or personal relationships that may have inappropriately influenced them in writing this article.

\section{Authors' contributions}

V.M. and P.M. contributed to the design and implementation of the research, to the analysis of the results and to the writing of the manuscript.

\section{Ethical considerations}

This article followed all ethical standards for research without direct contact with human or animal subjects.

\section{Funding information}

The authors received no financial support for the research, authorship and/or publication of this article.

\section{Data availability}

Data sharing is not applicable to this article, as no new data were created or analysed in this study.

\section{Disclaimer}

The views and opinions expressed in this article are those of the authors and do not necessarily reflect the official policy or position of any affiliated agency of the authors.

\section{References}

Amnesty International, 2004, It's in our hands: Stop violence against women, Alden Press, Oxford.

Arnold, B.T., 2009, 'Genesis': The New Cambridge Bible Commentary, Cambridge Press, Cambridge.

Assohoto, B. \& Ngewa, S., 2006, 'Genesis' in Africa Bible Commentary, Word Alive Publishers, Nairobi.

Atkinson, D., 1990, The message of Genesis 1-11: The Bible speaks today, Inter-Varsity Press, Downers Grove, IL.

Bezuidenhout, R. \& Naude, P., 2002, 'Some thoughts on public theology and its relevance for the South African context', Scriptura 79(1), 3-13. https://doi.org/ 10.7833/79-0-767

Boice, J.M., 1982, Genesis an expositional commentary, Ministry Resources Library, Grand Rapids, MI.
Bosch, D.J., 1995, Believing in the future: Toward a missiology of Western culture, Trinity Press International, Pasadena, TX.

Brade, K.A., 2009, 'Let the church stop saying "Amen": Domestic violence perceptions and experiences from a cohort of African-American clergy in Divinity School', PhD dissertation, Howard University.

Briggs, C.A., 1886, Messianic prophecy: The prediction of the fulfilment of redemption through the Messiah, Charles Scribner's Sons, New York, NY.

Bromell, D., 2011, What is public theology? Centre for Theology and Public Issues, viewed 18 July 2020, from https://www.otago.ac.nz/ctpi/otago032508.pdf.

Brown, L.B., 2015, 'Examining Masculine gender-role conflict and stress in relation to 318 religious orientation, spiritual well-being, and sex-role egalitarianism in latterday Saint Men', All theses and dissertations, p. 5771, viewed 20 July 2020, from https://scholarsarchive.byu.edu/etd/5771.

Chindomu, C. \& Matizamhuka, E.E., 2013, The Anglican diocese of Manicaland (Zimbabwe) mother's union addressing gender-based violence: The TAMAR campaign, E. Chitando \& S. Chirongoma (eds.), Sun Press, Stellenbosch.

Chisale, S.S., 2020, "Deliver us from patriarchy": A gendered perspective of the Evangelical Lutheran Church in Southern Africa and implications for pastoral care', Verbum et Ecclesia 41(1), a2003. https://doi.org/10.4102/ve.v41i1.2003

Chitando, E. \& Chirongoma, S. (eds.), 2013, Introduction: Justice not silence, Sun Press, Stellenbosch.

Clark, D.S., 2016, 'Beaten, battered and bruised: A critical analysis of how Christian leaders and laity respond to domestic violence against women', PhD dissertation, Regent University.

Clines, D.J.A., 1968, 'The image of God in man', Tyndale Bulletin 19, 53-104.

Collins, C.J., 2006, Genesis 1-4: A linguistic, literary, and theological commentary, P \& R Publishing, Phillipsburg, NJ.

Currid, J.D., 2003, Genesis volume 1: Genesis 1:1-25:18, Evangelical Press, Darlington.

Damron, E.H. \& Johnson, A.J., 2015, 'Violence against women in religious communities: An introduction', in A.J. Johnson (ed.), Religion and men's violence against women Springer, New York.

Darragh, N., 2007, 'The practice of practical theology: Key decisions and abiding hazards in doing practical theology', viewed 13 July 2020, from http://library.acu. edu.au/research/theology/ejournal/aejt_9/darragh.htm.

De La Torre, M.A., 2011, Genesis: A theological commentary on the Bible, Westminster John Knox Press, Louisville, KY.

English Standard Version (ESV), 2015, The reformation study bible, R.C. Sproul (ed.), Reformation Trust, Orlando, FL.

Eveson, P., 2001, The book of origins, Evangelical Press, Darlington.

Foh, S.T., 1974, 'What is the woman's desire?', The Westminster Theological Journal 37(5), 376-383.

Garner, S., 2015, 'Contextual and public theology: Passing fads or theological imperatives?', The New Zealand Journal of Christian Thought and Practice 22(1) 20-28.

Gillham, S., 2011, Gender based violence: The Bible's teaching on gender complementarity, NETS, Namibia.

Graham, L.K., 1992, Care of persons, care of worlds: A psychosystems approach to pastoral care and counselling, Abingdon Press, Nashville.

Graham, W., 2000, Cities of God, Routledge, London.

Grand, J., 2013, Breaking the silence on violence against Indigenous girls, adolescents and young women, viewed 15 July 2020, from https://www.unwomen.org/en/ digital-library/publications/2013/5/breaking-the-silence-on-violence-againstindigenous-girls.

Greidanus, S., 2004, 'Preaching Christ from the narrative of the fall', Bibliotheca Sacra 161(643), 259-273.

Grudem, W., 1994, Systematic theology: An introduction to Bible doctrine, Zondervan, Grand Rapids, MI.

Hamilton, V.P., 1990, The New International Commentary on the Old Testament: The book of Genesis 1-17, Eerdmans Publishing Company, Grand Rapids, MI.

Hart, I., 1995, 'Genesis 1:1-2:3 as a prologue to the book of genesis', Tyndale Bulletin 46(2), 315-336.

Hengstenberg, E.W., 1956, Christology of the Old Testament, and a commentary on the messianic predictions, 2 vols., Kregel Publications, Grand Rapids, MI.

Hoffmann, J.P. \& Miller, A.S., 1997, 'Social and political attitudes among religious groups: Convergence and divergence over time', Journal for the Scientific Study of Religion 36(1), 52-70. https://doi.org/10.2307/1387882

Kambarami, M., 2006, Femininity, sexuality and culture: Patriarchy and female subordination in Zimbabwe, University of Fort Hare, Alice, TX.

Kidner, D., 1967, Genesis: An introduction and commentary, Inter-Varsity Press, Illinois.

Kline, M.G., 1993, Kingdom prologue, South Hamilton Mass, Hamilton, MA.

Lerner, G., 1986, The creation of patriarchy, Oxford University Press, Oxford.

Louw, D.J., 1998, A pastoral hermeneutics of care and encounter a theological design for a basic theory, anthropology, method and therapy, Lux Verb, Wellington.

Magezi, V., 2019, 'Doing public pastoral care through church-driven development in Africa: Reflection on church and community mobilisation process approach in Lesotho', HTS Teologiese Studies/Theological Studies 75(4), a550. https://doi. org/10.4102/hts.v75i4.5501 
Magezi, V. \& Magezi, C., 2018, 'Migration crisis and Christian response: From Daniel De Groody's image of God theological prism in migration theology to a migration practical theology ministerial approach and operative ecclesiology', HTS Teologiese practical theology ministerial approach and operative ecclesiology', HTS Teologiese
Studies/Theological Studies 74(1), 4876. https://doi.org/10.4102/hts.v74i1.4876

Maisiri, O., 2015, 'Male headship and female submission in marriage among Africa Christians: A pastoral perspective', MA dissertation, University of Pretoria.

Masango, M.J., 2010, 'Is prophetic witness the appropriate mode of public discourse on the global economy?', HTS Teologiese Studies/Theological Studies 66(1) Art. \#772. https://doi.org/10.4102/hts.v66i1.772

McClure, B., 2012, 'Pastoral care', in J.M. McLemore (ed.), The Wiley Blackwell companion to practical theology, pp. 269-270, 1st edn., Blackwel Publishing, New Jersey.

McLemore, B.J.M., 2018, The living human web: A twenty-five year retrospective, Vanderbilt University, Nashville, TN.

Meyer, J., 2020, 'Investigating the nature of and relation between masculinity and religiosity and/or spirituality in a postcolonial and post-apartheid South Africa',
HTS Teologiese Studies/Theological Studies 76(1), a5663. https://doi.org/10.4102/ HTS Teologiese Stuc
hts.v76i1.5663

Moltmann, J., 1991, God in creation, HarperCollins Publishers, San Francisco, CA.

Moore, L.M. \& Vanneman, R., 2003, 'Context matters: Effects of the proportion of fundamentalists on gender attitudes', Social Forces 82(1), 115-139. https://doi. org/10.1353/sof.2003.0099

Ndulo, M., 2011, African customary law, customs and women's rights, viewed 11 July 2020, from https://zimlii.org/zw/pagefiles/african-customary-law-customs-andwomens-rights.pdf.

Njovana, E. \& Watts, C., 1996, 'Gender violence in Zimbabwe: A need for collaborative action', Reproductive Health Matters 4(7), 46-55. https://doi.org/10.1016/S0968 8080(96)90005-1

Ortlund, R.C., Jr., 1991, 'Male-female equality and male headship Genesis 1-3', in J. Piper \& W. Grudem (eds.), Recovering Biblical manhood and womanhood: A response to evangelical feminism, pp. 95-112, Crossway Books, Illinois.

Ozaki, R. \& Otis, M.D., 2017, 'Gender equality, patriarchal cultural norms, and perpetration of intimate partner violence: Comparison of male university students in Asian and European cultural contexts', Violence Against Women 23(9), 1076-1099. https://doi.org/10.1177/1077801216654575
Potgieter, S.D., 2015, 'Communities: Development of church-based counselling teams', HTS Teologiese Studies/Theological Studies 71(2), \#2050. https://doi. org/10.4102/hts.v71i2.2050

Rakoczy, S., 2004, 'Religion and violence: The suffering of women agenda: Empowering women for gender equity', Religion and Spirituality 16, 29-35.

Rayburn, C.A., 2015, 'Ecclesiastical policies versus lived social relationships: Gender parity, attitudes and ethics', in A.J. Johnson (ed.), Religion and men's violence against women, pp. 27-44, Springer, New York, NY.

Ross, A., 1985, 'Genesis' The Bible Knowledge Commentary, Victor Books, Wheaton, IL.

Simango, D., 2006, The image of God (Gen.1:26-27) in the Pentateuch: A biblical theological approach, North West University, Potchefstroom.

Simango, D., 2016, 'The Imago Dei (Gen 1:26-27): A history of interpretation from Philo to the present', Studia Historiae Ecclesiasticae 42(1), 172-190. https://doi. org/10.25159/2412-4265/1065

Sproul, R.C., 2011, 1-2 Peter, Crossway, Illinois.

Stephens, R.L. \& Walker, D.F., 2015, 'Addressing intimate partner violence in white evangelical and fundamentalist churches', in A.J. Johnson (ed.), Religion and men's violence against women, pp. 207-220, Springer, New York, NY.

Ushe, U., 2015, 'Eradicating sexual abuse and gender based violence in and America: Role of religious leaders', European Scientific Journal 11(5), 99-116.

Vawter, B.A., 1956, A path through genesis, Sheed \&Ward, New York, NY.

Vuola, E., 2016, 'Feminist theology, religious studies and gender studies: Mutual challenges', in L. Gemzoe, M. Keinanen \& A. Maddell (eds.), Contemporary encounters in gender and religion: European perspectives, pp. 307-334, Palgrave Macmillian, London.

Waltke, B.K. \& Fredricks, C.J., 2001, Genesis: A commentary, Zondervan, Grand Rapids, MI.

Wenham, G.J. 1987, Word Biblical Commentary: Genesis 1-15, D.A. Hubbard \& J.D.W. Barker (eds.), Thomas Nelson Publishers, Nashville, TN.

Westermann, C., 1987, Genesis 1-11: A commentary, Augsburg, Minneapolis, MN.

Wilkinson, D., 2002, The Message of Creation, Inter Varsity Press, Leicester.

Zimmerli, W., 1978, Old Testament theology in outline, T \& T Clark, Edinburgh. 